\title{
FACTORIAL ANALYSIS OF MASS MEDIA INFLUENCE ON ACADEMIC SPORTS
}

\author{
DEVELOPMENT
}

\author{
Benar Noshin ${ }^{1}$, Emami Mina ${ }^{2}$, Eftekhari Ozra ${ }^{3}$, Yeganeh Far Nastaran ${ }^{4}$, Khan Mohammadi Ali Mohammad ${ }^{5}$ \\ ${ }^{1}$ Associate Professor at University of Guilan, Iran \\ ${ }^{2}$ Master in Sport Management, University of Guilan, Iran \\ ${ }^{3}$ Master in Sport Management, University of Shomal, Iran \\ ${ }^{4}$ Lecturer at Islamic Azad University Bandar Anzali Branch, Iran \\ ${ }^{5}$ Master in Sport Management, University of Guilan, Iran
}

\begin{abstract}
Purpose: Main objective of this research was factorial analysis of mass media influence on academic sports development. Material: Methodology of the research was descriptive- correlation. Population of the research was composed of all referees, coaches and athletes participating in students' sports Olympiad of Iran Payam e Noor Universities in year 2014. Statistical sample of research was chosen randomly and consisted of 176 persons. Data gathering tool was a researcher made questionnaire; its superficial and content validity was approved by academic professors and media experts; also the stability of research tool was reported to be at an acceptable level. SPSS 23 software was used to analyze research data and also AMOS 24 software was used to analyze structure validity. Results: Findings showed there is a significant difference between current situation and desirable situation in all research dimensions. Also, factorial analysis of all research variables showed improvement of coaches' technical performance (0.86), improvement of referees' technical performance (0.85), and promotion of academic sport managers' awareness $(0.83)$ respectively are mostly influenced by mass media. Conclusion: It should be kept in mind that academic sports development is one of the factors of the entire country sports development. Hence, it is crucial to attend to different dimensions of student sport's aspects such as human, financial, planning and etc., especially in championship area to be able to further macro objectives of country's sports development. Considering current conditions, mass media should have a new perspective on academic sports in order to be able to attend to their responsibilities to further the excellence of country's sports.
\end{abstract}

Key words: Mass Media, Sports Development, Academic Sport, Women's Sport.

\section{Introduction}

Sports development requires attention to several dimensions at macro, middle, and micro levels. One of the most important components of sports is academic sport which is, based on evidence, highly influential on students' mental and physical health [12] and its main objective is to create the required context and appropriate opportunities for the pervasive stratum of college students, in order to attain healthy competitive and entertaining environment [5]. Physical activity and participation at university's sport programs can have a significant share in promotion of academic community's social, mental and physical health [8]. One of the main factors in cultural development is mass media $[1,6]$. The most essential objective of mass media in support of each country's national agenda could be sports development, which itself has several dimensions and axes [13].

Traditionally researchers have divided mass media into published and electronic. Published media includes newspapers and journals while electronic media includes radio, television, cinema, and internet (as modern media) [3, 10 and 11], all of which render direct influence on values and norms of the society since span of their activities includes a great number of the population of society [2]. Due to this reason, in most countries different media have established especial channels for sports [1].

Based on the discussion above, one of the important and influential factors in academic sports development is mass media. It is evident that effort to increase presentation of sport matches and programs as well as news coverage of women's sport in different sub-parts such as academic sport will be highly influential on more enhancement of participation and quality of performance of athletes, coaches and referees and will also result into development of other components of women's sport in the country. In this research, influence of television, radio, and press on academic sport development has been analyzed.

Analysis shows the existing distance between current situation in mass media and favorable situation of cultural development has a significant difference and this weakness is also observed in sports domain [1]. In their research Emami and Mallaei (2013) [4] have also reported that share of women's sport in TV news coverage wasvery minimal. Mahdavian Mashhadi (2008) [7] claimed mass media to play significant role in activating public, educative, championship, and technical sports especially in respect to women's sport. Ghasemi et al. (2008) described media role, particularly of the entire country TV, as important in development of championship sport and explained the importance of paying attention to all sport components in television. Academic sport has always

\footnotetext{
(c) Benar Noshin, Emami Mina, Eftekhari Ozra,

Yeganeh Far Nastaran, Khan Mohammadi Ali Mohammad, 2016

doi:10.15561/20755279.2016.0304
} 
been studied and analyzed from different aspects; but in Iran it still has not reached the necessary dynamics as a study domain. On the other hand, importance and necessity of attention to influential factors on academic sport development and lack of professional studies in this area make the significance of this research more obvious. As a result, in this research, to analyze the influence of television, radio, and press (as mass media) on academic sport development, athlete students participating in Iran's sports Olympiad of Payam e Noor Universities' students has been approached.

\section{Purpose}

The purpose of this research was factorial analysis of mass media influence on academic sports development.

\section{Material and methods}

Participants: population of the research consisted of all participating referees, coaches, and athletes in Iran sports Olympiad of Payam e Noor Universities, 2014. Statistical sample of research consisted of 176 persons who were selected randomly.

Research Design: methodology of this research is descriptive - correlation. To gather research data a researcher made questionnaire was utilized. In order to determine superficial and content validity of research tool, the questionnaire was approved by academic professors and media experts. Questionnaire's stability was reported to be $\alpha=0.91$.

Statistical Analysis: to analyze research data, descriptive statistics (frequency, frequency percentage) and inferential statistics (Kolmogrov-Smirnov test and Wilcoxon) using SPSS 23 software were performed; also to analyze structure validity and to present measurement models of research variables AMOS 24 software was used.

\section{Results of the research}

Demographic findings of the participating athletes are summarized in table 1 .

Table 1. Description of Personal Characteristics of Respondents

\begin{tabular}{|c|c|c|c|c|c|c|c|}
\hline 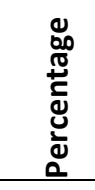 & 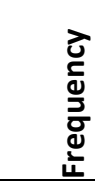 & Variable & & 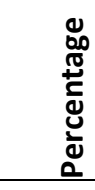 & $\begin{array}{l}\text { ̀े } \\
\frac{0}{0} \\
\frac{\partial}{0} \\
\frac{d}{4} \\
\end{array}$ & Variable & \\
\hline 78.7 & 137 & Less than 1 & Time Spent & 32.8 & 57 & $18-21$ & \multirow{4}{*}{ Age (Year) } \\
\hline 16.7 & 29 & $1-2$ & Watching & 48.9 & 85 & $22-26$ & \\
\hline 2.9 & 5 & $3-4$ & Sport & 13.2 & 23 & $27-31$ & \\
\hline 1.7 & 3 & More than 4 & $\begin{array}{l}\text { Programs on } \\
\text { TV (Hour) }\end{array}$ & 5.2 & 9 & $32-36$ & \\
\hline 69.4 & 120 & Less than 1 & $\begin{array}{l}\text { Time Spent } \\
\text { Listening to }\end{array}$ & 52.6 & 92 & $\begin{array}{l}\text { Physical } \\
\text { Education } \\
\text { Other than }\end{array}$ & \multirow{2}{*}{$\begin{array}{l}\text { Field of } \\
\text { Education }\end{array}$} \\
\hline 20.2 & 35 & $1-2$ & $\begin{array}{l}\text { Sport } \\
\text { Programs on }\end{array}$ & 47.4 & 83 & $\begin{array}{l}\text { Physical } \\
\text { Education }\end{array}$ & \\
\hline 5.2 & 9 & $3-4$ & Radio (Hour) & 6.3 & 11 & Associate Degree & \multirow{4}{*}{$\begin{array}{l}\text { Educational } \\
\text { Attainment } \\
\text { Sport } \\
\text { Background } \\
\text { (Year) }\end{array}$} \\
\hline 5.2 & 9 & More than 4 & & 85.1 & 148 & Bachelor & \\
\hline 36.6 & 63 & Less than 1 & $\begin{array}{l}\text { Time Spent } \\
\text { Reading }\end{array}$ & 8.6 & 15 & $\begin{array}{l}\text { Master and } \\
\text { Higher }\end{array}$ & \\
\hline 41.4 & 72 & $1-2$ & $\begin{array}{l}\text { Sports Press } \\
\text { (Hour) }\end{array}$ & 27.5 & 46 & $1-6$ & \\
\hline 14.4 & 25 & $3-4$ & & 46.7 & 78 & $7-12$ & \\
\hline 8.6 & 15 & More than 4 & & $\begin{array}{l}22.2 \\
3.6 \\
\end{array}$ & $\begin{array}{l}37 \\
6 \\
\end{array}$ & $\begin{array}{l}13-18 \\
19-24 \\
\end{array}$ & \\
\hline
\end{tabular}

Using Kolmogrov-Smirnov test, hypotheses of abnormal distribution of data was disapproved; hence to compare current situation and desirable role of mass media in academic sport development Wilcoxon test was used (Table 2). 
Table 2. Comparison of Current Situation and Desirable Role of Mass Media in Female Academic Sports Development

\begin{tabular}{|c|c|c|c|c|}
\hline \multicolumn{2}{|c|}{ Overall Result } & \multirow{2}{*}{$\begin{array}{l}\begin{array}{l}\text { Significance } \\
\text { Level }\end{array} \\
0.001^{*}\end{array}$} & \multirow{2}{*}{$\begin{array}{l}\text { Z } \\
\text { Statistics } \\
-9.151\end{array}$} & \multirow{2}{*}{$\begin{array}{l}\text { Variable } \\
\text { Promotion of Public Awareness of Academic Sport }\end{array}$} \\
\hline $\begin{array}{l}\text { Existence } \\
\text { Difference }\end{array}$ & of & & & \\
\hline $\begin{array}{l}\text { Existence } \\
\text { Difference }\end{array}$ & of & $0.001^{*}$ & -9.201 & Athletes' Performance Improvement \\
\hline $\begin{array}{l}\text { Existence } \\
\text { Difference }\end{array}$ & of & $0.001^{*}$ & -9.538 & Identification of Sports Talents \\
\hline $\begin{array}{l}\text { Existence } \\
\text { Difference }\end{array}$ & of & $0.001^{*}$ & -9.128 & Improvement of Coaches' Technical Performance \\
\hline $\begin{array}{l}\text { Existence } \\
\text { Difference }\end{array}$ & of & $0.001^{*}$ & -9.516 & Improvement of Referees' Technical Performance \\
\hline $\begin{array}{l}\text { Existence } \\
\text { Difference }\end{array}$ & of & $0.001^{*}$ & -9.732 & Promotion of Academic Sports Managers' Awareness \\
\hline $\begin{array}{l}\text { Existence } \\
\text { Difference }\end{array}$ & of & $0.001^{*}$ & -9.110 & Determining Academic Sports Strategies \\
\hline $\begin{array}{l}\text { Existence } \\
\text { Difference }\end{array}$ & of & $0.001^{*}$ & -10.088 & Fair Allotment of Academic Sport Facilities \\
\hline $\begin{array}{l}\text { Existence } \\
\text { Difference }\end{array}$ & of & $0.001^{*}$ & -9.527 & Increased Research on Academic Sport \\
\hline $\begin{array}{l}\text { Existence } \\
\text { Difference }\end{array}$ & of & $0.001^{*}$ & -9.836 & Increasing Allocated Budget for Academic Sport \\
\hline $\begin{array}{l}\text { Existence } \\
\text { Difference }\end{array}$ & of & $0.001^{*}$ & -9.452 & Increasing Sponsors and Public Investment \\
\hline $\begin{array}{l}\text { Existence } \\
\text { Difference }\end{array}$ & of & $0.001^{*}$ & -9.804 & News Coverage of Academic Sport \\
\hline $\begin{array}{l}\text { Existence } \\
\text { Difference }\end{array}$ & of & $0.001^{*}$ & -9.826 & $\begin{array}{l}\text { Increased Employment and Entrepreneurship at Students' } \\
\text { Olympiads }\end{array}$ \\
\hline $\begin{array}{l}\text { Existence } \\
\text { Difference }\end{array}$ & of & $0.001^{*}$ & -9.951 & Increased Audiences for Academic Sports \\
\hline $\begin{array}{l}\text { Existence } \\
\text { Difference }\end{array}$ & of & $0.001^{*}$ & -9.431 & Familiarity with Academic Sport Champions \\
\hline
\end{tabular}

Table 3 demonstrates the factor analysis of role of television, radio, and press, separately, on sports development.

Table 3. Factor Analysis of Role of Television, Radio, and Press on Academic Sport Development

\begin{tabular}{|c|c|c|c|c|c|}
\hline & & $\begin{array}{l}\text { Standard } \\
\text { Regression } \\
\text { Weight of } \\
\text { TV } \\
\text { Influence } \\
\text { on } \\
\text { Research } \\
\text { Items }\end{array}$ & $\begin{array}{l}\text { Standard } \\
\text { Regression } \\
\text { Weight of } \\
\text { Radio } \\
\text { Influence } \\
\text { on } \\
\text { Research } \\
\text { Items }\end{array}$ & $\begin{array}{l}\text { Standard } \\
\text { Regression } \\
\text { Weight of } \\
\text { Press } \\
\text { Influence on } \\
\text { Research } \\
\text { Items }\end{array}$ & Significance Level \\
\hline $\begin{array}{l}\text { Promotion of Public } \\
\text { Awareness of Academic } \\
\text { Sport }\end{array}$ & $<--$ & .677 & .644 & .643 & $* * *$ \\
\hline $\begin{array}{l}\text { Athletes' Performance } \\
\text { Improvement }\end{array}$ & $<---$ & .715 & .748 & .715 & $* * *$ \\
\hline $\begin{array}{l}\text { Identification of Sport } \\
\text { Talents }\end{array}$ & $<---$ & .667 & .672 & .707 & $* * *$ \\
\hline
\end{tabular}




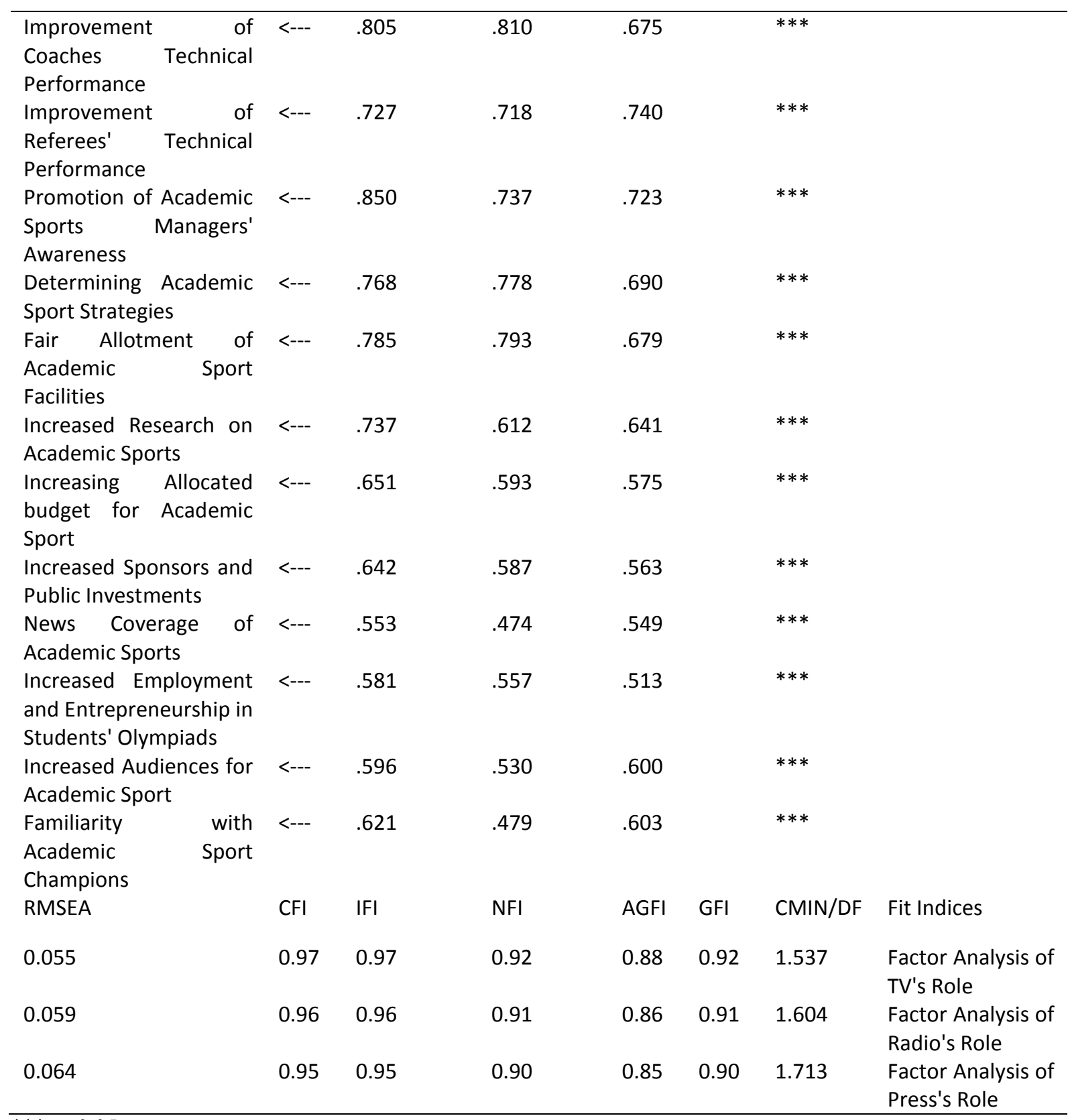

***:p $<0.05$

From table 3, it is evident that factors of promotion of academic sports managers' awareness, improvement of coaches' technical performance, and improvement of referees' technical performance respectively take the highest influence from television, radio, and press.

Table 4. Fit Indices of Measurement Model for Level of Influence of Mass Media on Academic Sport Development

\begin{tabular}{llllllll}
\hline RMSEA & CFI & IFI & NFI & AGFI & GFI & CMIN/DF & Fit Indices \\
0.062 & 0.97 & 0.97 & 0.93 & 0.86 & 0.91 & 1.673 & $\begin{array}{l}\text { Factor Analysis of Role of } \\
\text { Mass Media }\end{array}$ \\
\hline
\end{tabular}




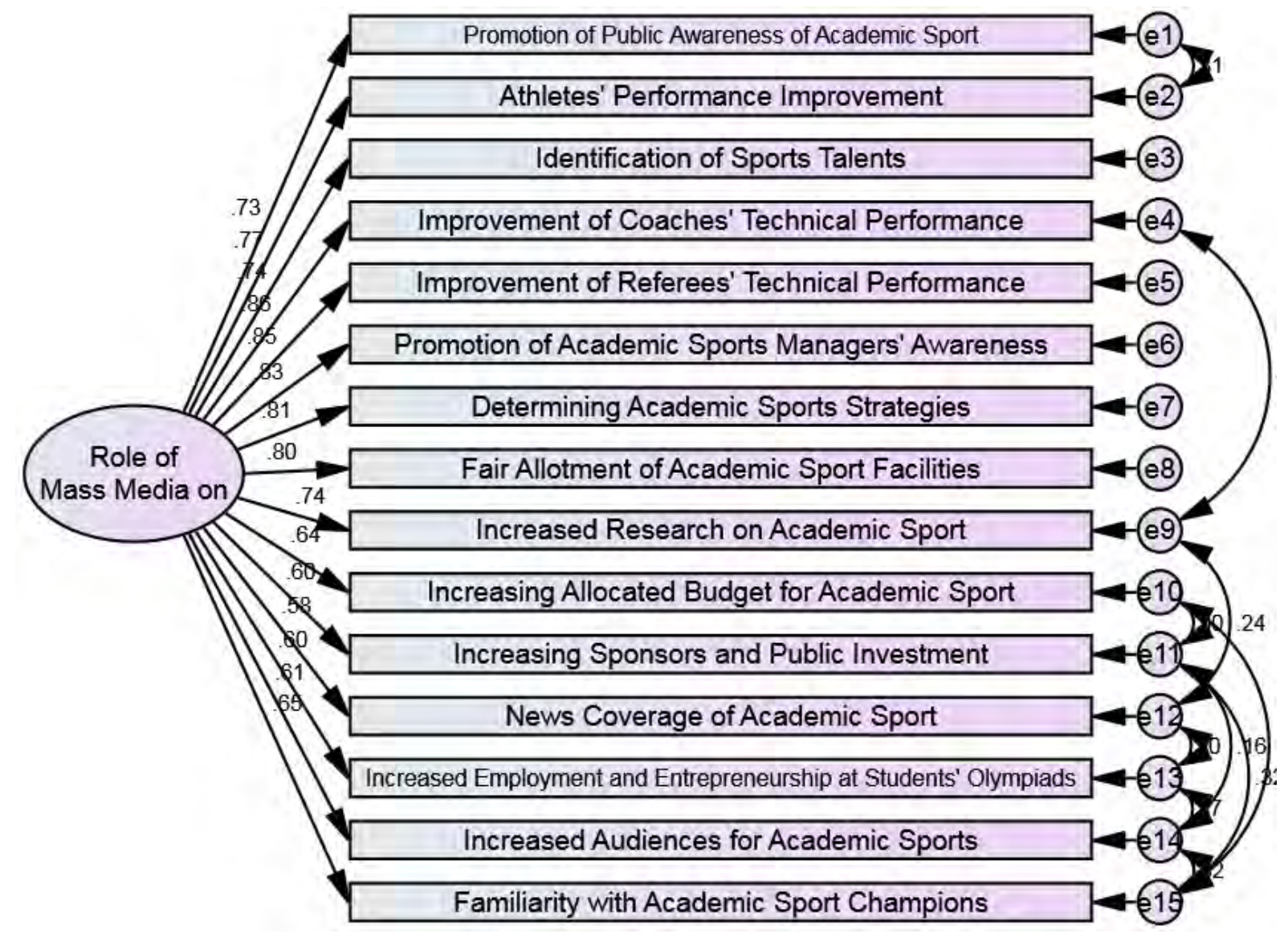

Figure 1. Measurement Model for Level of Influence of Mass Media on Iran's Female Academic Sport Development

Based on measurement model for level of influence of mass media on Iran's female academic sport development (figure 1), improvement of coaches' technical performance (0.86), improvement of referees' technical performance $(0.85)$, and promotion of academic sport managers' awareness $(0.83)$ respectively are the mostly influenced variables by mass media.

\section{Discussion}

Results of the research clarified that there is a significant difference between current situation and desirable situation of influence of media under investigation in all research variables. In other words, mass media does not perform appropriately on their designated roles. Hence, media is expected to enhance their effort to achieve their prophecy regarding academic sport development. Rahimi Ajdadi (1996) [9] had indicated television, radio, and press have had a crucial and significant role in progression and development of women's sport in society and had been able to expand people's beliefs to criticize as well as make progress in the society. It is worth mentioning despite conduction of several studies over different periods of time on influences of mass media on different sport areas, yet there are still deficiencies in achieving the relevant objectives in case of media most especially in terms of women's sport. This represents a gap between mass media performance in broadcast of women's sport and results of the conducted researches.

Results of factorial analysis of this research showed that television renders respectively the most influence on promotion of academic sport managers' awareness $(0.85)$, improvement of coaches' technical performance $(0.80)$, and fair allotment of academic sport facilities (0.78). Based on results of research, it seems those engaged in different TV channels should pay much more attention to their performance in terms of sports; since television is amongst the most influential media on development of different sport areas which is, based on the related factor analysis, influential on development of dimensions of academic sport.

Results of factor analysis on radio demonstrated that this media is respectively influential on improvement of coaches' technical performance (0.81), fair allotment of academic sports facilities (0.79), and determining academic sports strategies $(0.78)$. In other part, factor analysis of extensible variables that are influenced by press 
respectively include improvement of referees' technical performance (0.74), increasing academic sport managers' awareness (0.72), and improvement of athletes' performance.

Finally, overall factorial analysis of mass media influence on academic sport development showed improvement of coaches' technical performance (0.86), improvement of referees' technical performance (0.85), and increasing academic sport managers' awareness $(0.83)$ are respectively the most influenced variables by mass media. Based on research findings, technical performance in women's sport events and matches is one of the most essential factors that is influenced by mass media. In other words, presentations and media reports of women's events will play significant role in increasing coaches, referees, and athletes' performance quality. This might be due to lack of visibility of valuable efforts of women in sports. Therefore, based on research results and respondents' comments, audio and visual broadcast and presentation of women's sports on mass media is motivational sign to increase women's performance quality to even higher levels in sports fields. Motivation to being seen, encouraged, cheered, and supported by audiences both in sport arena and media is amongst important reasons to enhance women's performance quality in sports. Therefore, mass media such as television, radio, and press have a crucial and effective role to make this happen. Also, based on final measurement model of this research, media has a high influence on increasing academic sports managers' awareness especially in terms of women's sports. Since mass media especially television, due to extensive audience coverage, are important and effective tools to increase awareness and to direct beliefs and cultures, all over the world a great amount of attention is paid to them by audiences. Considering the research results, mass media due to this serious role, shall exert effort to transfer information and awareness such as sending messages and criticisms of those involved in sports as well as people of society to concerned managers and others in charge as much as possible. As it has been argued, one of the indirect communication channels of athletes or non-athlete people in society with concerned high officials is through influential media such as television and radio.

Other results of the final factor analysis of research demonstrated that determining academic sport strategies, increased academic sport research, identification of sport talents, promotion of public awareness about academic sport, fair allotment of academic sport facilities, increased budget allocation to academic sport, increased sponsors and public investment, increased employment and entrepreneurship in students' Olympiads, and increased audiences for students' sports are also variables highly influenced by mass media in Iran.

\section{Conclusions}

It is evident that information dissemination role of media could be utilized as a tool for increase of public awareness level in respect to academic sport as well as to attract college students toward sports. Media, by taking advantage of advertising, information dissemination and education about sport and its advantages, can cause more active participation of female college students in different fields of public sports as well as championships in universities. At the same time, if women's sport is broadcasted by media, it probably would increase investment and financial supports both from public and private sectors in terms of women's sport; since, one of main objectives of financial supporters is to be introduced to public and attract even more consumers. This would be possible in shadow of media's higher supports from women's sport. Another dimension of academic sport development by mass media is increased employment and entrepreneurship; this means support and introduction of entrepreneurs and others engaged in the field by mass media would perform as a motivational force for others to be creative and innovative at students' sport events and Olympiads.

\section{Conflict of interests}

The author declares that there is no conflict of interests.

\section{References}

1. Afroozeh MS, Hamidi M, \& Elahi A. Identification of Vantage points of Universities' Sports Council Members Regarding Media Approach to Sports. Journal of Research Communication, 2012; 19(1): 5570.

2. Asadi A, \& Rezaee Soufi M. Analysis of current situation and desirable role of mass media in development of volleyball sport field amongst students of sports sciences. Communication Management in Sports Media, 2014; 2(5): 59-63.

3. Black J \& Bryant J. Introduction to Media Communication (4th ED) Dubuque. IA: Brown \& Benchmark; 1995.

4. Emami M, \& Mallaei M. Analysis of Sports News Content: Case Study of Channel 3. Communication Management in Sports Media, 2013; 1(3): 15-24.

5. Ghasemi H, Tejari F, Kohandel M, \& Khodayari A. Media activities on sport. Bamdad e Ketab; 2008.

6. Hamidi M, Elahi A, Akbari Yazdi H, \& Hamidi M. Students Sport of Islamic Republic of Iran, View and Development Strategy. Sports Management Studies, 2011; 12: 13-26. 
7. Mahdavian Mashhadi M. Comparison of Current Situation and Desirable Role of Mass Media in Women's Sport. First National Conference of Sport Management of Shomal University, 2008; P. 24-26.

8. Mehdizadeh R, \& Andam R. Solutios for Public Sport Development in Iran's Universities. Sports Management Studies, 2014; 22: 15-38.

9. Rahimi Ajdadi F. Analysis of content of women's role in mass media mediums (Unpublished master's thesis). Islamic Azad University, Tehran, Iran; 1996.

10. Roberts R \& Olson JS. Wining is the Only Thing: Sport in America Since 1945. Baltimore, MD: Johns Hopkins university press; 1989.

11. Sage GH. Wining is the Only thing: Sport in America Since 1945. Baltimore, MD: Johns Hopkins university press; 1998.

12. Sotiriadou K, Shilbury D. The Attraction, retention, Transation, and Nurturing Process of Sport Development: Some Australian Evidence. Journal of Sport Management, 2008; 22: 247-272.

13. Zarifi M, \& Davoudi K. National Media and Development of Public Sports. Journal of Communication Research, 2012; 19(69): 119-134.

Information about the authors:

Benar Noshin; Assistant professor; http://orcid.org/00000003-3765-916X; noshin.benar@yahoo.com; Faculty of Physical Education and Sport Sciences, University of Guilan; Box 1841, Rasht, Iran.

Emami Mina; Master in Sport Management; http://orcid.org/0000-0002-2057-2423;

m.emami1991@yahoo.com; Faculty of Physical Education and Sport Sciences, University of Guilan; Box 1841, Rasht, Iran.

Eftekhari Ozra; Master in Sport Management; http://orcid.org/0000-0001-7445-7351;

ozra.eftekhari@gmail.com; University of Shomal; P.O.Box 731.

Amol, Mazandaran, Iran.

Yeganeh Far Nastaran; Lecturer; http://orcid.org/0000-00016314-0949; blackscorpion_002@yahoo.com; Islamic Azad University of Bandar Anzali Branch; P.O.Box:43145-1655, Bandar Anzali, Iran.

Khan Mohammadi Ali Mohammad; Master in Sport Management; $\quad$ http://orcid.org/0000-0002-2519-5727; reza.k1999@gmail.com; Faculty of Physical Education and Sport Sciences, University of Guilan; Box 1841, Rasht, Iran.

Cite this article as: Benar Noshin, Emami Mina, Eftekhari Ozra, Yeganeh Far Nastaran, Khan Mohammadi Ali Mohammad. Factorial analysis of mass media influence on academic sports development. Physical education of students, 2016;3:32-38. doi:10.15561/20755279.2016.0304

The electronic version of this article is the complete one and can be found online at: http://www.sportpedu.org.ua/html/arhive-e.html

This is an Open Access article distributed under the terms of the Creative Commons Attribution License, which permits unrestricted use, distribution, and reproduction in any medium, provided the original work is properly cited (http://creativecommons.org/licenses/by/4.0/deed.en).

Received: 01.06.2016

Accepted: 19.06.2016; Published: 28.06.2016 